\title{
$\mathrm{Tc} 99 \mathrm{~m}$ 방사성 동위원소 검사에서 열결절을 보이지 않는 양측성 Warthin씨 종양 1 예
}

\author{
선병원 이비인후과 \\ 박문규·권순영·김영선 · 유홍균

\section{A Case of Bilateral Warthin's Tumor without Accumulation of Technetium 99m Pertechnetate}

\author{
Mun-Kyu Park, MD, Soon-Young Kwon, MD, Young-Sun Kim, MD and Hong-Kyun Yoo, MD \\ Department of Otolaryngology-Head and Neck Surgery, Sun General Hospital, Taejon, Korea
}

\section{- ABSTRACT -}

Warthin's tumor is common benign tumor of the parotid gland. This tumor is well encapsulated, different from pleomorphic adenoma which has pseudopods, and easily cured by simple tumor excision. Because Warthin's tumor is composed of oncocytes, it generally accumulates of technetium $99 \mathrm{~m}(\mathrm{Tc}-99 \mathrm{~m})$ pertechnetate in a radionuclide scan. Scintigraphy with $99 \mathrm{mTc}$-pertechnetate is used for the differential diagnosis. But authors have recently experienced a case of no visible hot accumulation of $99 \mathrm{mTc}$-pertechnetate in a 67 -year-old man with multicentric and bilateral Warthin's tumor. (J Clinical Otolaryngol 2001;12:125-128)

KEY WORDS : Parotid gland · Warthin's tumor · Cold nodule.

\section{서 론}

이하선에는 조직병리학적으로 여러가지 형태의 종양 이 발생하며, 조직병리학적 분류에 따라 치료방법과 술 후 결과도 달라지므로 이하선 종양의 수술전 진단은 중 요하다. ${ }^{1)}$ 이하선에 생기는 종양은 대부분이 양성종양으 로, 다형성 선종이 가장 많고, Warthin씨 종양이 두 번 째로 많다. 2- 4)

논문접수일 : 2000년 12월 18일

심사완료일 : 2001년 3월 15일

교신저자 : 권순영, 301- 070 대전광역시 중구 목동 10- 7 선병원 이비인후과

전화 : (042) 220- 8466, 8890. 전송 : 042- 221- 3678

E-mail : en_ed@sunhospital.com
Warthin씨 종양은 위족이 있는 다형성 선종과는 달 리 피막이 잘 형성되어 있어, ${ }^{5)} W$ arthin씨 종양으로 추 정진단이 가능한 경우에는 술 후 합병증이 적은 종양적 출술만으로도 엽절제술과 동일한 치료결과를 얻을 수 있을 것으로 생각되어진다. ${ }^{6)}$ 특히 Warthin씨 종양은 조 직학적으로 종양세포(oncocyte) 로 구성되어 종양세포 종과 함께 T c99m pertechnetate를 이용한 동위원소 검 사에서 열결절로 나타나는 경우가 많아서 T c99m pertechnetate를 이용한 동위원소 검사는 세침흡입검사와 함께 술 전에 Warthin씨 종양을 감별진단하는 중요한 검사로 생각되어진다. ${ }^{12)}{ }^{2) 8)}$

그러나 저자들은 최근 67세 남자에게 발생한 T c99m pertechnetate를 이용한 동위원소 검사에서 열결절을 보이지 않은 Warthin씨 종양 1예를 경험하였기에 보고 


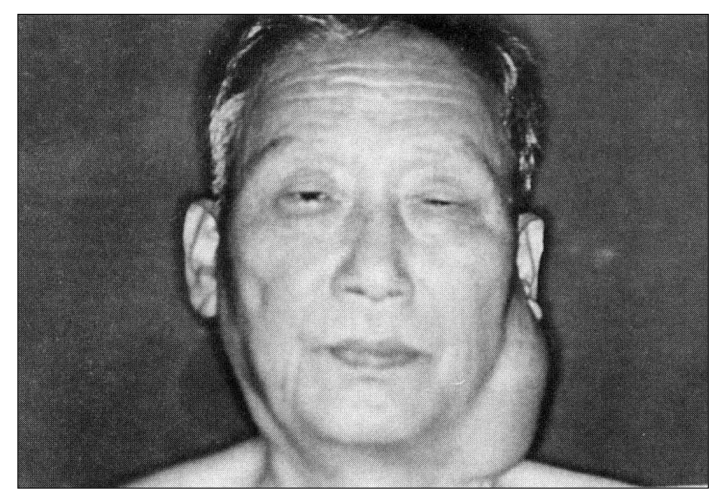

Fig. 1. The left mass is about $9 \times 7 \times 6 \mathrm{~cm}$ and have $\mathrm{sm}$ ooth, rubbery-hard and tenderness nature. The right mass is about $3 \times 4 \times 2 \mathrm{~cm}$ and have movable, smooth, and non-tenderness nature.

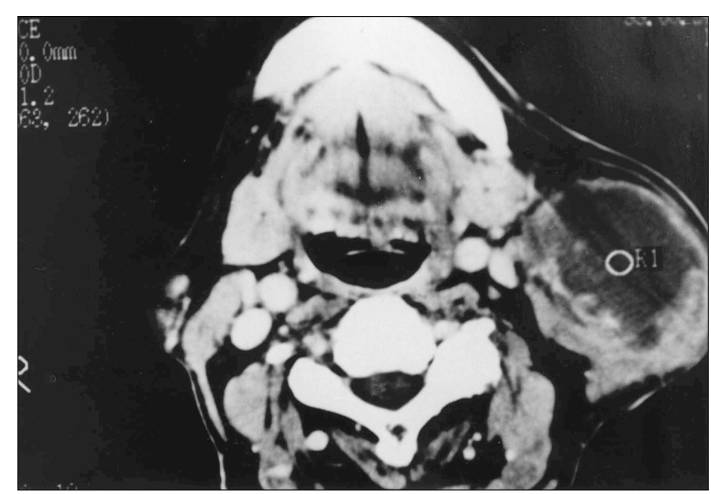

Fig. 2. About $6 \mathrm{~cm}$ sized solid mass in left parotid gland and $2 \mathrm{~cm}$ sized solid mass in right parotid gland are seen.

하는 바이다.

\section{증 례}

67세 남자환자가 12년 전부터 좌측 이하선 부위에 종물이 있었고 1년 전부터 우측 이하선 부위에 종물이 있었다. 2년 전부터 좌측 이하선 부위의 종물의 크기가 증가하였으며 내원 2개월 전부터 빠른 증가를 보였다. 2년전 좌측안면마비가 발생하였으나 자연적으로 회복 되었다. 이학적 검사에서 좌측 종물은 $9 \times 7 \times 6 \mathrm{~cm}$ 으 로 가동성이 있고, 표면이 매끈하고 단단하고, 압통이 있었으며 우측은 $3 \times 4 \times 2 \mathrm{~cm}$ 으로 가동성이 있고, 표 면이 매끈하고 압통은 없었다(Fig. 1). 세침흡인세포검

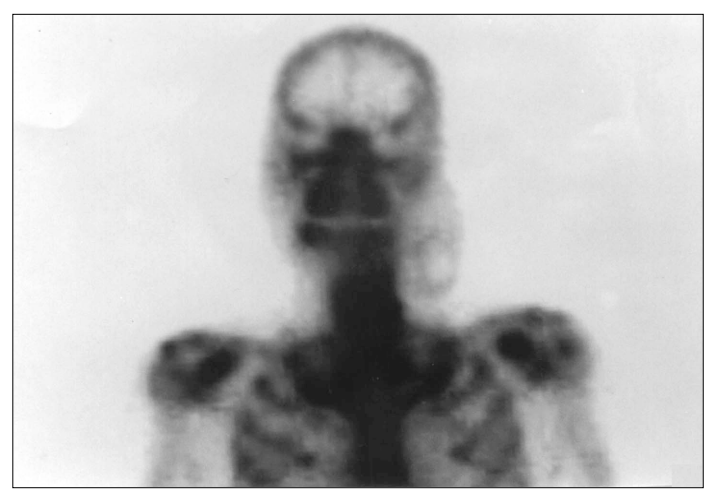

Fig. 3. Increased uptake on soft mass lesion on left neck portion and thyroid gland portion are noted.

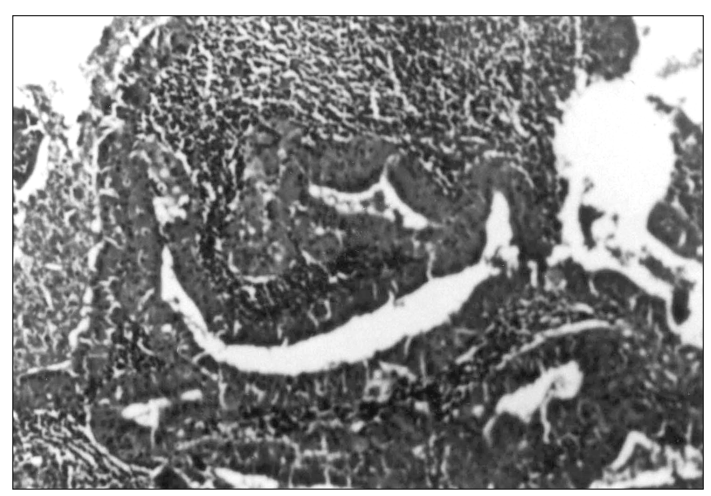

Fig. 4. Lymphoid stroma and double layered epithelium ( H-E stain $\times 200)$.

사상 양측 모두 많은 염증세포와 세포형질내 풍부한 호 산성 과립세포의 소견을 보였다. 경부전산화단층촬영에 서 이하선에서 발생한 것으로 생각되는 양측성, 다엽성 의 종물이 조영증강전 영상에서 보였는데 좌측 이하선 부위에서는 $6 \mathrm{~cm}$ 크기의 고체성 종물이 관찰되었고 우 측 이하선 부위에서는 $2 \mathrm{~cm}$ 크기의 고체성 종물이 관찰 되었다. 조영증강후 좌측 이하선부위종양은 낭성변화 및 조영증강소견을 보였으나 우측 이하선부위종양은 낭성 변화 및 조영증강소견을 보이지 않았으며 임파선 종대 는 보이지 않았다(Fig. 2). T c99m pertechnetate를 이 용한 동위원소 검사에서 열결절의 소견은 보이지 않았 다Fig. 3). 1999년 6월 1일 종양과 함께 좌측 표재성 이하선 절제술 시행하였으며 술 후 8일째 퇴원하였다. 적출된 종물은 3 부분으로 구성되었는데 첫 번째는 $8 \times$ 
$7 \times 6 \mathrm{~cm}$ 의 분엽성, 난원형의 조직이었으며. 조직단면 소견상 괴사와 낭성변화의 소견을 보였다. 두 번째와 세 번째는 난원형의 부드러운 조직으로 각각 $2 \mathrm{~cm}$ 과 $1.5 \mathrm{~cm}$ 의 직경을 보였다. 병리조직학적소견상 이중층의 호산 성 상피와 임파성 기질로 구성된 소견을 보였다Fig. 4).

\section{고 찰}

Warthin씨 종양은 주로 이하선의 미부에 서서히 커지 는 무증상의 종물로 발견되며 중년 남성에 호발하는 것 으로 보고되고 있다. ${ }^{910)}$ 이 종양의 약 $10 \%$ 에서는 양측 성으로 발생하며 다발성인 경우도 있는데 ${ }^{2-411) 12)}$ 본 예에서도 양측성이며 다발성이었다.

Warthin씨 종양은 형태학적으로 경계가 명확한 막 (capsule) 을 가지는 표면이 매끄러운 구형 또는 난원형 종물이고 주위조직에 침윤이 거의 없으며 단면상에서 진한 점액질로 채워진 다양한 크기의 다낭성 공간을 보 인다. ${ }^{213)}$ 조직병리학적으로는 미토콘드리아가 풍부한 호산성 상피, 즉 종양세포(oncocyte) 와 임파성 기질로 구성되어 있고 상피는 이중층으로 구성되어 있다. ${ }^{13)}$

진단은 이학적 검사, 세침흡인세포학검사, 동위원소촬 영, 초음파검사, 전산화단층촬영, 자기공명영상 등이 도 움이 되고 확진은 병리조직학적 검사에 의한다. 세침흡 인세포학검사는 숙련된 임상가와 병리학자의 경우 Warthin씨 종양에서 우수한 양성 진단률을 보이고 있지만 보고자에 따라서는 민감도가 떨어진다는 보고가 있다. ${ }^{2) 8)}$ Warthin씨 종양은 특징적으로 방사선 동위원소인 T c99m pertechnetate를 농축시키는 경향이 있어 대부분 열결 절이 나타나는 것으로 알려져 있고, 열결절이 나타날 경 우 진단적 가치가 매우 높은 것으로 알려져 있다. ${ }^{12) 718)}$ Warthin씨 종양에서 열결절이 나타나는 이유는 종양내 의 상피세포인 종양세포(oncocytes) 가 혈액으로부터 pertechnetate와 같은 거대 음이온, 즉 동위원소를 흡 수하고 관강 내(ductal lumen) 으로 배출하는데, Warthin 씨 종양의 경우에는 배출관과의 교통이 없기 때문에 그 결과로 동위원소가 종양에 지속적으로 축적되어서 나 타나는 것으로 알려져 있다. ${ }^{14) 15)}$

하지만 T c99m pertechnetate를 이용한 동위원소 검사에서 열결절이 나타나지 않은 본 증례에서와 같이
Warthin씨 종양에서 열결절이 나타나지 않은 경우를 Gates $^{17)}$ 는 30\% (3/10), Schmitt등 ${ }^{18)}$ 은 31\%(8/26), Yamashita등 ${ }^{19)}$ 은 23.8\% (3/13), Haraguchi등 ${ }^{16)}$ 은 $31 \%$ (8/26) 라고 보고하였는데, ${ }^{16-19)}$ 그 이유는 상피세 포의 활동성 감소나 수적감소 때문이라고 하였다. ${ }^{1)}$

술 전에 Warthin씨 종양을 진단하는 것은 종양을 치 료하는데 큰 도움이 되며 Warthin씨 종양은 Tc99m pertechnetate를 이용한 동위원소 검사에서 대부분 열 결절을 나타내는 것으로 알려져 있으나 열결절을 나타 내지 않는 경우도 있으므로 여기에 대한 주의가 필요할 것으로 생각되어 진다.

중심 단어 : 이하선종양 Warthin씨 종양 냉결헐.

\section{REFERENCES}

1) Weinstein GS, Harvey RT, Zimmer W. Technetium- $99 m$ Pertechnetate Salivary Gland Imaging: Its Role in the Diagnosis of Watthin's Tumor. J Nucl Med 1994;35:179-83.

2) Lee KS, Tae K, Kim HS, Park CW. Three cases of multifocal Warthin's tumor. Korean J Otolaryngol 1997;40: 1471-5.

3) Shikhani AH, Shikhani LT, Kuhajda FP. Warthin's tumor associated neoplasm: Report of two cases and review of the literature. ENT J 1993;72:264-73.

4) Turnbull AD, Frazell EL. Multiple tumors of the major salivary glands. Am J surg 1969;118:787-9.

5) Batsakis JG, El-Naggar AK. Pathology consultation Warthin's tumor. Ann Otol Rhinol Laryngol 1990;99:588-91.

6) Choi JO, Ju EJ, Kim WJ, Choi HY, Chu HR, Choi G, et al. Selection of surgical treatment for Warthin's tumors of parotid experience in 20 cases. Korean J Otolaryngol 1999; 42:501-4.

7) Yasuro Y, Miyuki N. Bilateral papillary cystadenoma lymphomatosum of the parotid gland without accumulation of technetium-99m pertechnetate. J Oral Maxillofac Surg 1991:49:401-4.

8) Lindberg LG, Akerman M. Aspiration cytology of salivary gland tumors: Diagnostic experience from 6 years of routine laboratory work. Laryngoxcope 1986;86:584-94.

9) Dietert SE. Papillary cystadenoma lymphomatosum (Warthin's tumor) in patients in a General hospital over a 24year period. Am J Clin Path 1975;63:866-75.

10) Woods JE, Chong GC, Beahrs OH. Experience with 1360 primary parotid tumors. Am J Surg 1975;130:460-3.

11) Kurzer A, Villegas LF. Bilateral simultaneous Warthin's tumor in women. Plast Reconst Surg 1986;78:87-90.

12) Lefor AL, Ord RA. Multiple synchronous bilateral Warthin's tumors of the parotid glands with pleomorphic adenoma. Oral Surgery Oral Medicine Oral Pathology 1993; 76:319-23.

13) William W, Shockley. Parotid tumors In: The Neck-Diag- 
J Clinical Otolaryngol 2001;12:125-128

nosis and Surgery, First Edition, edited by Shockley WW. Pillsburg III. Hc St. Louis: Mosby Year Book.;1994. p.265-94.

14) Chapnik JS. The controversy of Warthin's tumor. Laryngoscope 1983;93:695-716.

15) Liu RS, Yeh SH, Hsu DF. Salivary scintigraphy with vitamin C stimulation: an aid in differentiating unilateral parotitis from Warthin's tumor. Eur J Nucl Med 1990;16: 689-91.

16) Haraguchi S, Murakani Y, Maruyama T, Tateno H, Fufimura A, Urao Y. RI scintigraphy of parotid adenolym- phoma. J Otolaryngol Jpn 1985;88:911.

17) Gates GA. Radiosialographic aspects of salivary gland disorders. Laryngoscope 1972;82:115.

18) Schmitt G, Lehmann G, Strotages MW, Wehmer W, Reinecke V, Teske HJ, Rottinger EM. The diagnostic value of sialography and scintigraphy in salivary gland disease. Br J Radiol 1976;49:326.

19) Yamashita T, Tomoda K, Izumi H. Analysis of 15 cases of adenolymphoma developed from parotid gland. Head and Neck Tumor 1984;11:359. 